Diabetologia 9, 97-101 (1973)

(C) by Springer-Verlag 1973

\title{
ORIGINALS
}

\section{Influence of an $\alpha$-Amylase Inhibitor (BAY d 7791) on Blood Glucose, Serum Insulin and NEFA in Starch Loading Tests in Rats, Dogs and Man*}

\author{
W. Puls and U. Keup \\ Institute of Pharmacology, Bayer AG, Wuppertal, Germany \\ Received: August 18, 1972, accepted: November 13, 1972
}

Summary. An $\alpha$-amylase inhibitor isolated from wheat was used in experiments involving rats, dogs and healthy volunteers. The hyperglycaemia and hyperinsulinaemia resulting from starch loading could be reduced dose dependently by the inhibitor. Its inhibitory effect is specific and limited to $\alpha$-amylase. In loading tests with cooked starch the effect on blood sugar is markedly diminished.

Key words: $\alpha$-Amylase inhibitor, starch loading, starch digestion, blood glucose, serum insulin, NEFA, rats, dogs, men.
Starch is the predominant ingredient of human food. The break-down of starch is catalyzed in the gastrointestinal tract by salivary and pancreatic $\alpha$ amylase, resulting in maltose. Maltose is bydrolyzed to glucose by maltases localized in the brush border of the small intestine. The degradation of starch to glucose proceeds very rapidly. A few minutes after the ingestion of starch a marked hyperglycaemia leading to hyperinsulinaemia is observed. Both phenomena are highly undesirable in patients suffering from diabetes mellitus, obesity or hyperlipoproteinaemia. Retardation of the digestion of starch should lead to a diminution of these two postprandial phenomena. It should be possible to obtain this retardation by the concomitant administration of an inhibitor of $\alpha$-amylases. This hypothesis was investigated using an $\alpha$-amylase inhibiting protein which had been isolated from wheat and administered to rats, dogs and humans.

\section{Material and Methods}

The following materials were used: raw starch, from wheat, supplied by Firma Kröner/Tbbenbüren, W-Germany; $\alpha$-amylase inhibitor (BAY d 7791), supplied by D. Schmidt, Biochemisches Laboratorium Bayer AG, Wuppertal, W-Germany, and an oral hypoglycaemic agent, Glisoxepide, supplied by Bayer AG. The experiments were carried out on male Wistar rats, SPF (Winkelmann), weighing between $130-170 \mathrm{~g}$. The rats were kept on a standard diet (Altromin-R) with free access to tap water, at a room temperature of $24 \pm 1^{\circ} \mathrm{C}$ and a light-dark phase from 07.00 to $17.00 \mathrm{~h}$. The following dogs were used: male and female Beagle dogs, kept in single cages at a room temperature of $16-22^{\circ} \mathrm{C}$ and on a standard diet (Altromin-H) with free access to tap water. Food was witheld from the rats and dogs $16 \mathrm{~h}$ prior to each experiment. Free access to water was maintained.

* The results were presented in part at the Seventh Congress of the German Diabetes Association, Bad Nauheim (Puls und Schmidt, 1972).
Seven healthy male volunteers, accustomed to take part in such investigations, took part in these experiments. Their age ranged from $23-44$ years (mean 33 years); their body weight ranged from $72-92 \mathrm{~kg}$ (mean $84 \mathrm{~kg}$ ); their height varied between $171-189 \mathrm{~cm}$ (mean $179 \mathrm{~cm}$ ). These men were asked to abstain from food and fluids containing calories or caffeine for twelvo hours prior to the experiment. During the experiment they continued to carry out their usual physically light work, as far as the timing of the experiment permitted. None of the participants had a family history of diabetes mellitus. Starch was administered in form of a $\mathbf{0 . 4 5}$ per cent saline suspension. The inhibitor, BAY d 7791, was dissolved in a few drops ethanol $(96 \%)$ and then added to the starch suspension. Glisoxepide was suspended in saline and added to the starch suspension. Rats were given $2.5 \mathrm{~g}$ starch in $10 \mathrm{ml} /$ $\mathrm{kg}$, dogs were given $1.5 \mathrm{~g}$ in $2.5 \mathrm{ml} / \mathrm{kg}$ and the volunteers received $100 \mathrm{~g}$ of starch in $175 \mathrm{ml} /$ person.

Blood was obtained from rats by puncture of the retroorbital venous plexus, from dogs by puncture of leg or ear veins, and from volunteers by venepuncture.

Estimation of blood glucose was carried out in the Technicon ${ }^{\odot}$ Auto-Analyzer [1]. Serum insulin (IRI) was estimated by radioimmunological assay [2], the non esterfied fatty acids (NEFA) by a colorimetric method [3]. For the estimation of starch in the gastrointestinal tract of rats the animals were killed by a blow on the head and immediately eviscerated. The contents of stomach, small and large intestine were washed out separately with icecold $30 \%$ ethanol. The washing fluids were twice centrifuged and washed in pure ethanol. The obtained starch was hydrolyzed in $2 \mathrm{~N}$ sulphuric acid and after appropriate neutralization the free glucose was determined in the Auto-Analyzer.

\section{Results}

\section{Experiments with raw starch}

\section{Starch contents in the gastrointestinal tract of rats}

When rats are tube-fed $300 \mathrm{mg}$ of raw starch as an aqueous suspension the starch is almost completely digested within two hours (Fig. 1). After two hours 
only $8 \%$ of the administered starch is found in the stomach and small intestine. By the addition of $9 \mathrm{mg}$ of amylase inhibitor, however, $54 \%$ is recovered in the

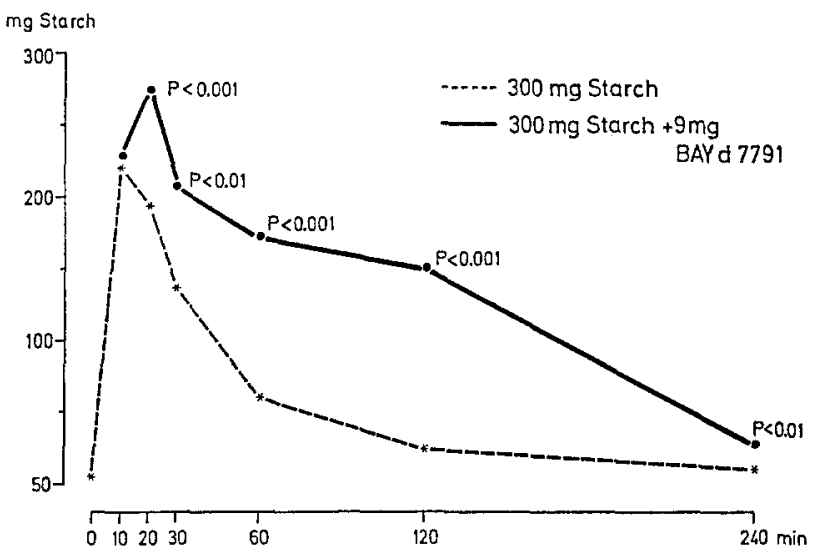

Fig. 1. Starch contents in the stomach and intestine of rats after oral loading with $300 \mathrm{mg}$ of raw starch $\pm \mathrm{BAY}$ d. $7791 /$ rat $(n=6)$

same period. Under the influence of the inhibitor starch digestion is only completed after four hours. This means that with a concomitant administration of BAY d 7791 starch remains in the intestine about twice as long. Since the starch contents in the large intestine did not differ from that of the control during the entire experiment, it is evident that no undigested starch reached the large intestine.

\section{Blood glucose in rats and dogs after starch loading \pm amylase inhibitor}

After the administration of raw starch $(2.5 \mathrm{~g} / \mathrm{kg}$ rat) blood glucose rises from 50 to $116 \mathrm{mg} / 100 \mathrm{ml}$ within $10 \mathrm{~min}$ (Fig. 2). The maximal level is reached with slightly more than $140 \mathrm{mg} / 100 \mathrm{ml}$ after 20 to 60 min. The addition of BAY d 7791 causes a dose dependent depression of this postprandial hyperglycaemia. The dose of BAY d 7791 represented in the curve $\boldsymbol{\Lambda}-\boldsymbol{\Lambda}$ (Fig. 2) is slightly smaller than the dose shown in Fig. 1.

Under the influence of the inhibitor the decrease of NEFA levels is markedly diminished (Fig. 2).

If however rats are fed glucose, saccharose or maltose, the amylase inhibitor exerts no influence on the resulting hyperglycaemia, nor has it any effect on the blood glucose level of fasting animals.

The anti-hyperglycaemic effect of BAY d 7791 can also be demonstrated in dogs (Fig. 3).

Blood glucose and serum insulin in healthy volunteers 土amylase inhibitor

In comparison with rats and dogs the inhibitor has a strikingly similar effect on the blood glucose in healthy volunteers, who were given $100 \mathrm{~g}$ of raw starch by mouth (Fig. 4 and Table 1). In man the consumption of $100 \mathrm{~g}$ starch results in an increase of serum insulin (IRI) from $15 \mu \mathrm{U}$ to 50 and $51 \mu \mathrm{U} / \mathrm{ml}$ resp. after 30 and $45 \mathrm{~min}$. This rise in serum insulin is reduced in a dose dependent fashion by BAY d 7791 .

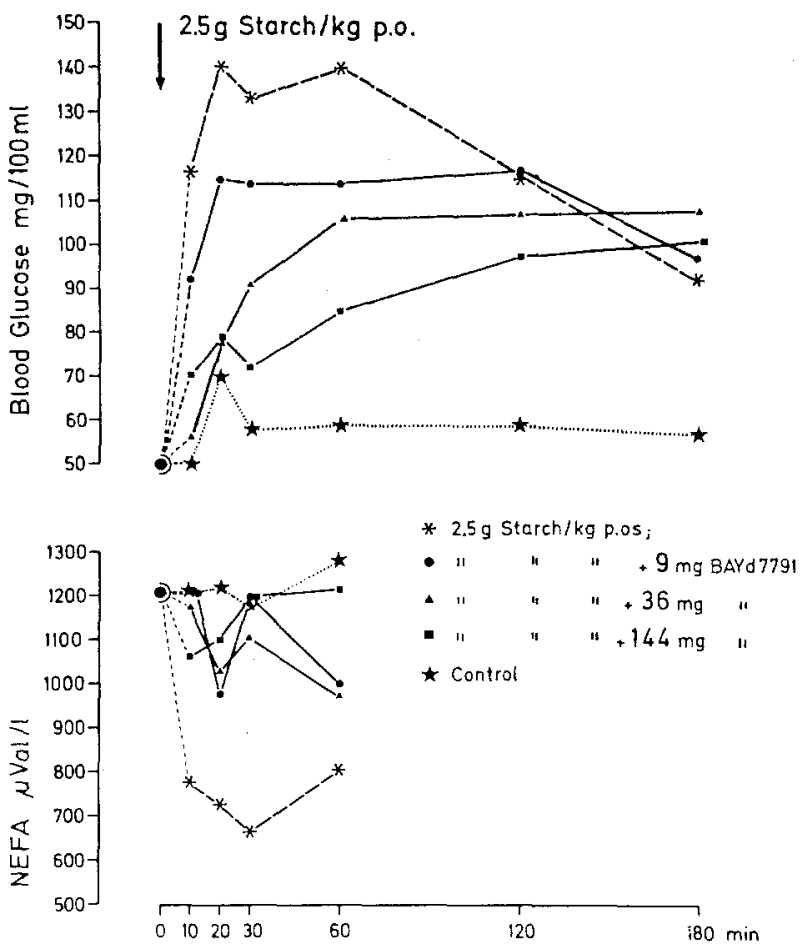

Fig. 2. Dose response relationship of blood glucose after oral feeding with $2.5 \mathrm{~g}$ of starch $/ \mathrm{kg}$ rat \pm BAY d 7791 $(n=6)$. All blood glucose values within $60 \mathrm{~min}$ after starch loading are significantly $(P<0.001)$ lower in the groups with BAY d 7791 than in the group with starch alone. This also applies to the NEFA values

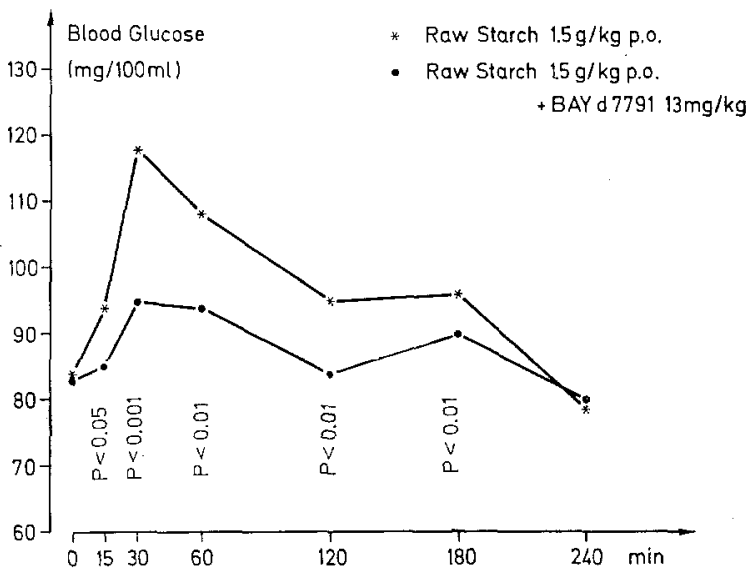

Fig. 3. Blood glucose in dogs after loading with $1.5 \mathrm{~g}$ of starch $/ \mathrm{kg} \pm \mathrm{BAY}$ d $7791(n=7)$

Combined application of an amylase inhibitor and an oral hypoglycaemic agent in man

It is well known that oral hypoglycaemic agents of the sulfonylurea type, when used in conjunction with oral glucose loading, lower the resulting hypergly- 
caemia. Here glisoxepide [4] (15 $\mu \mathrm{g} / \mathrm{kg}$ body weight) was used in combination with raw starch loading. The effect on the hyperglycaemia after starch loading is
The rise of serum insulin caused by starch loading is slightly increased and more prolonged by the additional application of glisoxepide. If glisoxepide and

Table 1. Changes of blood glucose in $m g / 100 \mathrm{ml} \pm l s$ and serum insulin in $\mu U / m l \pm l s$ after starch loading $\pm B A Y d 7791$

\begin{tabular}{|c|c|c|c|c|c|c|c|c|}
\hline Blood glucose & $\begin{array}{l}\text { Initial } \\
\text { value, } \\
\mathrm{mg} / \\
100 \mathrm{ml}\end{array}$ & 15 & 30 & 45 & 60 & 90 & 120 & $180 \mathrm{~min}$ \\
\hline Starch loading & $102 \pm 8.2$ & $+21 \pm 11$ & $+42 \pm 12$ & $+35 \pm 17$ & $+19 \pm 26$ & $+22 \pm 14$ & $+15 \pm 9.3$ & $+6 \pm 8.0$ \\
\hline $\begin{array}{l}+\mathrm{BAY} d \mathrm{~d} 7791 \\
350 \mathrm{mg}\end{array}$ & $113 \_7.3$ & $\pm 1 \pm 7.7$ & $\pm 22 \pm 13$ & $+22 \pm 18$ & $+17 \pm 20$ & $+15 \pm 18$ & $+11 \pm 12$ & $-\underline{5 \pm 4.4}$ \\
\hline$+\underset{700 \mathrm{mg}}{+\mathrm{BAY} d 791}$ & $105 \pm 3.3$ & $+14 \pm 6.1$ & $\stackrel{+12 \pm 10}{=}=$ & $\pm 12 \pm \frac{15}{P}$ & $\begin{array}{l}+14 \pm 13 \\
0.05\end{array}$ & $+15 \pm 7.1$ & +9 土 6.4 & $+5 \pm 4.1$ \\
\hline $\begin{array}{l}\text { Significant diffe } \\
\text { Serum insulin }\end{array}$ & $\begin{array}{l}\text { ences in co } \\
\mu U / m l\end{array}$ & pparison wit & starch contr & $1=P P<$ & $\begin{array}{l}0.01 \\
0.001\end{array}$ & & & \\
\hline Starch loading & $15 \pm 8.3$ & $+17 \pm 14$ & $+35 \pm 27$ & $+36 \pm 28$ & $+20 \pm 11$ & $+17 \pm 9.1$ & $+18 \pm 15$ & $+10 \pm 6.7$ \\
\hline$+\underset{350 \mathrm{mg}}{\mathrm{BAY} d 791}$ & $13 \pm 4.5$ & $+6 \pm 6.0$ & $+19 \pm 15$ & $+21 \pm 14$ & $+13 \pm 11$ & $+13 \pm 9.0$ & $+15 \pm 13$ & $+7 \pm 7.9$ \\
\hline $\begin{array}{l}+\mathrm{BAY} \mathrm{d} 7791 \\
700 \mathrm{mg}\end{array}$ & $13 \pm 2.4$ & $+9 \pm 5.5$ & $+13 \pm 8.1$ & $+11 \pm 15$ & $+13 \pm 13$ & $+10 \pm 10$ & $+12 \pm 13$ & $+6 \pm 5.5$ \\
\hline
\end{tabular}

Table 2. Changes of blood glucose in $\mathrm{mg} / 100 \mathrm{ml} \pm \mathrm{ls}$ and serum insulin in $\mu U / \mathrm{ml} \pm \mathrm{ls}$ after starch loading $\pm B A Y a r 791 \pm$ glisoxepide

\begin{tabular}{|c|c|c|c|c|c|c|c|c|}
\hline Blood glucose & $\begin{array}{l}\text { Initial } \\
\text { value, } \\
\mathrm{mg} / \\
100 \mathrm{ml}\end{array}$ & 15 & 30 & 45 & 60 & 90 & 120 & $180 \mathrm{~min}$ \\
\hline Starch loading & $102 \pm 8.2$ & $+21 \pm 11$ & $+42 \pm 12$ & $+35 \pm 17$ & $+19 \pm 26$ & $+22 \pm 14$ & $+15 \pm 9.3$ & $+6 \pm 8.0$ \\
\hline $\begin{array}{l}+\mathrm{BAY} \mathrm{d} 7791 \\
350 \mathrm{mg}\end{array}$ & $113 \pm 7.3$ & $\pm 1 \pm 7.7$ & $\pm 22 \pm 13$ & $+22 \pm 18$ & $+17 \pm 20$ & $+15 \pm 18$ & $+11 \pm 12$ & $-5 \pm 4.4$ \\
\hline + glisoxepide & $106 \pm 5.0$ & $+15 \pm 8.1$ & $+31 \pm 19$ & $\pm-5 \pm 23$ & $-7 \pm 29$ & $-9 \pm 13$ & $-3 \pm 11$ & $-5 \pm 4.6$ \\
\hline $\begin{array}{l}+ \text { BAY d } 7791 \\
350 \mathrm{mg}+ \\
\text { glisoxepide }\end{array}$ & $109 \pm 10$ & $\pm-\underline{6} \pm-\underline{9} \cdot \underline{4}$ & $\pm \quad 7 \pm 19$ & $=7 \pm 32$ & $-30 \pm 28$ & $=33 \pm 11$ & $\begin{array}{l}-23 \pm 14 \\
==\end{array}$ & $-7 \pm 11$ \\
\hline $\begin{array}{l}\text { Significant diffe } \\
\text { Serum insulin }\end{array}$ & $\begin{array}{l}\text { ence in con } \\
\mu U / m l\end{array}$ & arison withs & arch contro & $\begin{array}{l}P \\
==-P\end{array}$ & $\begin{array}{l}0.05 \\
0.01 \\
0.001\end{array}$ & & & \\
\hline Starch loading & $15 \pm 8.3$ & $+\mathbf{1 7} \pm \mathbf{1 4}$ & $+35 \pm 27$ & $+36 \pm 28$ & $+20 \pm 11$ & $+17 \pm 9.1$ & $+18 \pm 15$ & $+10 \pm 6.7$ \\
\hline$+\underset{350 \mathrm{mg}}{\mathrm{BAY}}$ & $13 \pm 4.5$ & $+6 \pm 6.0$ & $+19 \pm 15$ & $+21 \pm 14$ & $+13 \pm 11$ & $+13 \pm 9.0$ & $+15 \pm 13$ & $+7 \pm 7.9$ \\
\hline + glisoxepide & $10 \pm 2.2$ & $+19 \pm 9.5$ & $+52 \pm 34$ & $+45 \pm 28$ & $+31 \pm 29$ & $+28 \pm 26$ & $+25 \pm 27$ & $+16 \pm 20$ \\
\hline $\begin{array}{c}+ \text { BAY d } 7791 \\
\text { 350 mg+ } \\
\text { glisoxepide } \\
\end{array}$ & $12 \pm 3.2$ & $+14 \pm 9.5$ & $+47 \pm 26$ & $+38 \pm 30$ & $+24 \pm 25$ & $+14 \pm 9.9$ & $+11 \pm 9.3$ & $+8 \pm 10$ \\
\hline
\end{tabular}

quite similar to that obtained in glucose loading (Fig. 5 and Table 2). If, in a starch tolerance test, BAY d 7791 is administered in addition to glisoxepide, no hyperglycaemia is observed. On the contrary a marked hypoglycaemia begins to develop after $30 \mathrm{~min}$ and continues up to at least $90 \mathrm{~min}$.
BAY d 7791 are applied in combination, under the same conditions, the initial rise of serum insulin is quite similar but returns to normal in a shorter time.

The finding in our experiments with starch loading in healthy volunteers were confirmed in diabetic and obese patients $[5,6,7]$. 


\section{Experiments with cooked starch}

The effect of the $\alpha$-amylase inhibitor is markedly diminished when rats are loaded with cooked starch instead of raw starch. As can be seen from Fig. 6 more than ten times higher doses are necessary to obtain a significant smoothing of the postprandial hypergly. caemia.
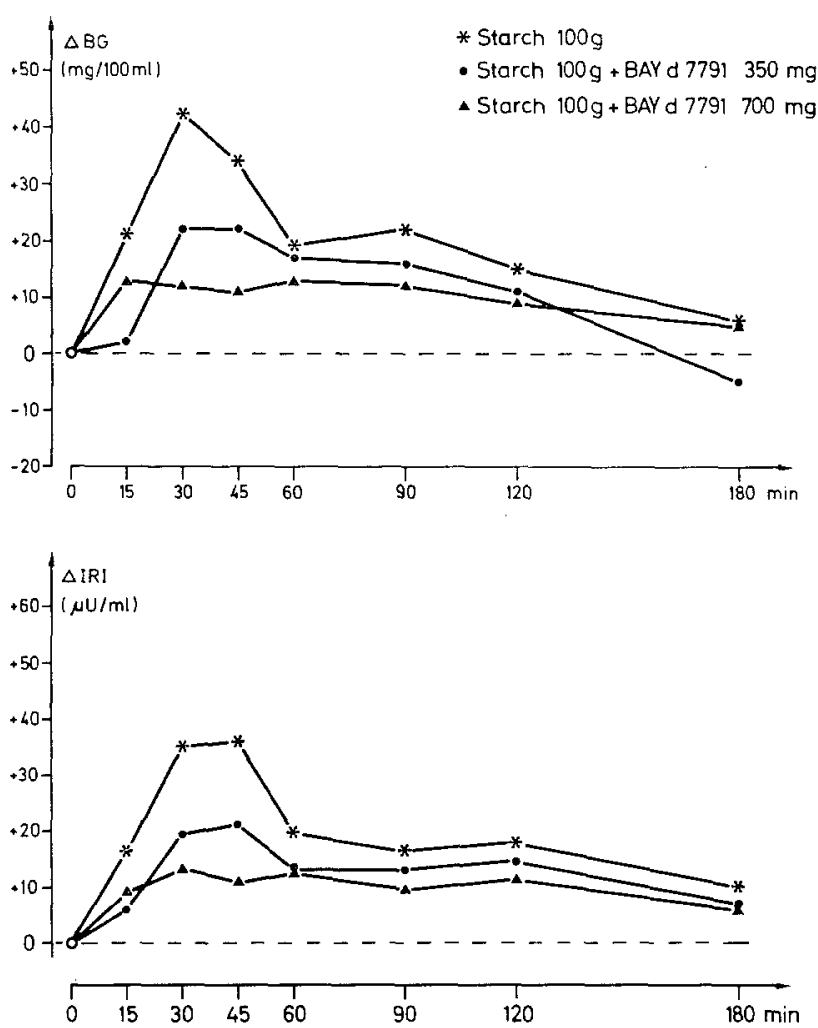

Fig. 4. Blood glucose and serum insulin in healthy volunteers $(n=7)$ after loading with $100 \mathrm{~g}$ of raw starch/person \pm BAY d 7791

\section{Discussion}

Amylase inhibitors have been known since 1943 $[8,9,10]$. Their activity was only demonstrated by in vitro-inhibition against salivary and pancreatic amylases.

The study of the literature did not reveal any description of amylase inhibition as a pharmacological principle, nor of amylase inhibitor activity against human pancreatic amylase in vitro or in vivo.

The new $\alpha$-amylase inhibitors, which were isolated and characterized in detail [11], are proteins with a mean molecular weight of 16000 . They have isoelectric points of 5.6 and 5.9 and are thermostabile up to $70^{\circ} \mathrm{C}$. These new inhibitors differ markedly from those previously described in their physico-chemical and excellent pancreatic $\alpha$-amylase inhibitory properties.

Our original intention to retard the gastrointestinal digestion of raw starch could be fully verified in the experiments described above (Fig. 1). Since the pro- duction of glucose resulting from the break-down of raw starch is suppressed per unit time, the resulting hyperglycaemia is consequently reduced. This in turn causes a diminished secretion of insulin in both man and animals. This smoothing effect on the postprandial hyperglycaemia should be of advantage in all forms of
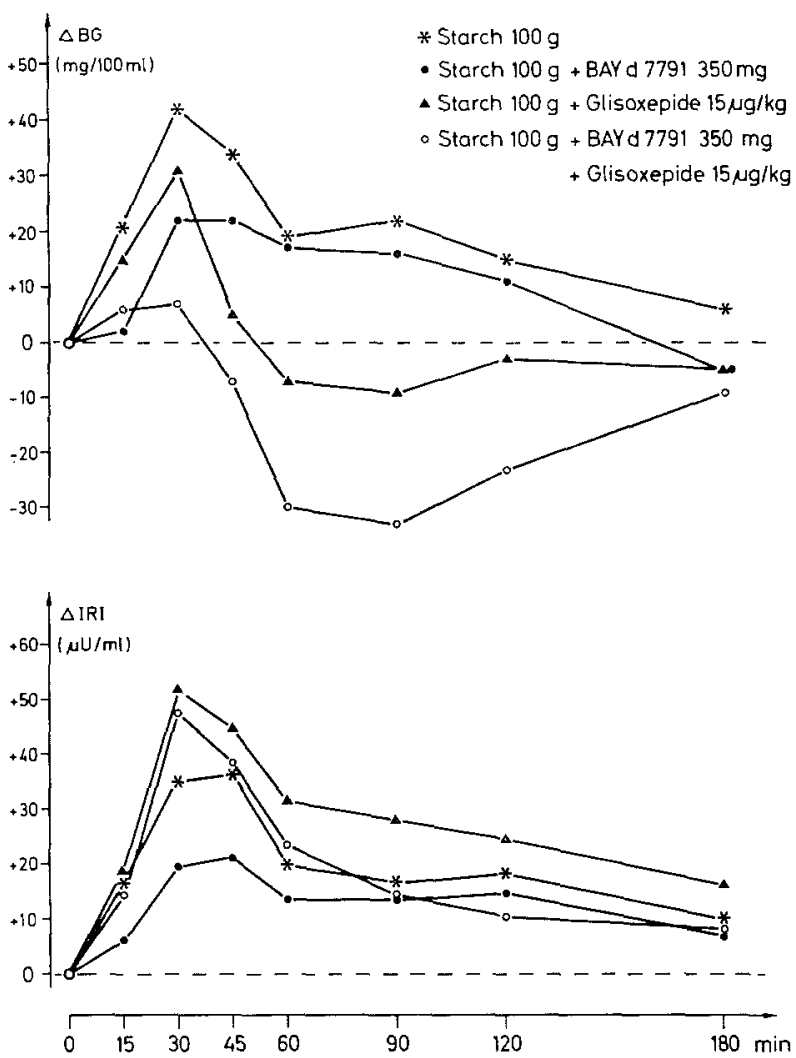

Fig. 5. Blood glucose and serum insulin in healthy volunteers after starch loading and additional application of BAY d $7791 \pm$ glisoxepide

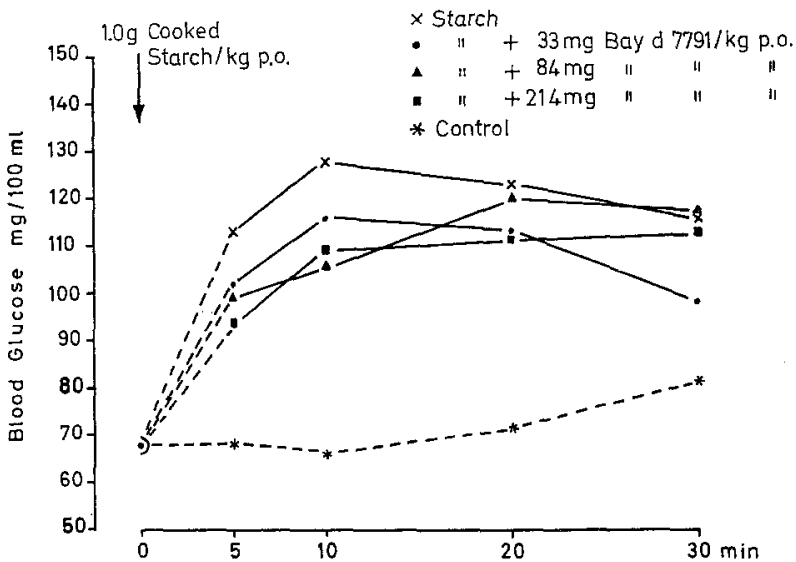

Fig. 6. Blood glucose in rats after oral loading with $1.0 \mathrm{~g}$ of cooked starch $/ 20 \mathrm{ml}$ saline $/ \mathrm{kg}$ rat $\pm \mathrm{BAY} \mathrm{d} 7791(n=$ 6). $33 \mathrm{mg} \mathrm{BAY} \mathrm{d} 7791 / \mathrm{kg}$ had no significant effect. 84 and $214 \mathrm{mg} / \mathrm{kg}$ showed significant differences only after $5 \mathrm{~min}$ $(P<0.05, P<0.01)$ and after $10 \min (P<0.01, P<0.01)$ 
diabetes mellitus. The diminished insulin secretory response might primarily be of use in obese patients, in whom the insulin response often is exaggerated [12] and exerts a strong lipogenic effect [13]. Moreover insulin promotes reactive hypoglycaemias and a consequent sensation of hunger.

It is apparent from the effectiveness in starch load. ing on one hand and the ineffectiveness on glucose- and disaccharide-loading on the other that the effect of BAY d 7791 must lie in the specific inhibition of hydrolysis of raw starch. The activity of other digestive enzymes, e.g. proteases and lipases, is not affected by BAY d 7791 in vitro [11]. However due to its protein nature BAY d 7791 is fairly rapidly degraded by pepsin and trypsin. If the inhibition of $\alpha$-amylase by BAY $d$ 7791 was complete, the finding of undigested starch in the large intestine, resulting in the occurrence of diarrhoea, might be expected. The absence of diarrhoea, in spite of repeated dosing with BAY d 7791, can be taken therefore to be due to the enzymatic degradation of the inhibitor.

The experiments described above were carried out using raw starch. If cooked starch is used (Fig. 6) the smoothing effect on hyperglycaemia is markedly less pronounced even though 10 -fold higher doses of the inhibitor had been administered. The reason for this difference in activity of the inhibitor may be due to the destruction of the membrane of the cooked starch grain. By a process of swelling, the surface of each grain increases, giving the amylase easier access to the chains of amylose. This would mean that even those small amounts of amylase which are not blocked by the inhibitor, suffice for the hydrolysis of starch. Presumably the affinity of amylase to starch is greater than the affinity of this inhibitor to the enzyme. For this reason, inhibitors with a greater affinity to amylase could be advantageous for therapeutic use.

\section{References}

1. Hoffman, W.S.: A rapid photoelectric method for the determination of glucose in blood and urine. J. biol. Chem. 120, 51 (1937).
2. Hales, C.N., Randle, P.J.: Immunoassay of insulin with insulin-antibody precipitate. Biochem. J. 88, $137-146$ (1963).

3. Konitzer, K., Voigt, S., Solle, M.: Eine einfache Methode zur kolorimetrischen Bestimmung der unveresterten langkettigen Fettsäuren im Plasma. Acta biol. german. 12, 502 (1964).

4. Puls, W., Frerichs, H., Gerhards, E., Kolb, K.H., Kroneberg, G.: Pharmakologie eines neuen Antidiabeticums. X. Symposium der Deutschen Gesellschaft für Fortschritte auf dem Gebiot der Inneren Medizin in Freiburg am 22.10.1971.

5. Gries, F.A., Hessing, J., Grüneklee, D., Daweke, H., Frerichs, H., Jahnke, K., Miss, H.D., Otto, H., Zumfelde, C.: Einfluß eines $\alpha$-Amylase-Inhibitors auf die Stärketoleranz. Seventh Congress of the German Diabetes Association, Bad Nauheim, 1972.

6. Otto, H., Zumfelde, C., Jahnke, K., Miss, H.D., Frerichs, H., Daweke, H., Grüneklee, D., Hessing, J., Gries, F. A.: Wirkung eines Amylaseinhibitors (BAY d 7791) auf Blutglucose und Seruminsulin nach Verabfolgung stärkehaltiger Nahrungsmittel. Seventh Congress of the German Diabetes Association, Bad Nauheim, 1972.

7. Frerichs, H., et al.: A novel pancreatic amylase inhibitor (BAY d 7791). Experimental studies on rats and clinical observations in normal and obese, diabetic and non diabetic subjects. 8th Annual Meeting of the European Association for the Study of Diabetes, Madrid, 1972.

8. Kneen, E., Sandstedt, R.M.: An amylase inhibitor from certain cereals. J. Amer, chem. Soc. 65, 1247 (1943).

9. Kneen, E., Sandstedt, R.M.: Distribution and general properties of an amylase inhibitor in cereals. Arch. Biochem. 9, 238-249 (1946).

10. Shainkin, R., Birk, Y.: $\alpha$-Amylase inhibitors from wheat. Isolation and characterization. Biochim. Biophys. Acta 221, 502-513 (1970).

11. Schmidt, D.D., Wingender, W.: In preparation.

12. Karam, J.H., Grodsky, G.M., Forsham, P.H.: Excessive insulin response to glucose in obese subjects as measured by immuno-chemical assay. Diabetes 12, 197-204 (1963)

13. Ditschuneit, H., Faulhaber, J.D. : Fettsucht und Diabetes mellitus. Ärztl. Forsch. 24, 313-325 (1970).

Dr. W. Puls

Dr. U. Keup

Institute of Pharmacology

Bayer AG.

D-5600 Wuppertal

Postfach 130105

Federal Republic of Germany 